\title{
Evaluation of growth, yield attributing characters, yield and economics of wheat (Triticum aestivum L.) in integrated weed management practice under the temperate conditions of Kashmir
}

\author{
RAYEES A. SHAH \\ National Agricultural Innovation Project, SRLS-3, KUPWARA(J\&K) INDIA
}

\begin{abstract}
A field experiment was conducted under the temperate conditions of Kashmir during Rabi season 2011-12 and 201213 to study the effect of integrated weed management on growth, yield attributing characters, yield and economics of wheat (Triticum aestivum L.). The results revealed significant increase in grain yield and growth characters, like crop emergence/mm row length, No. of tillers / $\mathrm{m}$ row length at 60 DAS and plant height $(\mathrm{cm})$ at 60 DAS with isoproturon @ $1 \mathrm{~kg}$ a. i /ha at 32 days after sowing + hand weeding at 30 days after sowing during both the years. Among the weed control measures isoproturon @ $1 \mathrm{~kg}$ a. $\mathrm{i} /$ ha at 32 days after sowing + hand weeding at 30 days after sowing recorded higher grains/ear, 1000 grain weight (g), highest grain yield ( 4.22 tonnes/ha) as well as straw yield (6.10 tonnes/ha) which was at par with the weed free but; isoproturon @ $1 \mathrm{~kg}$ a. i /ha tank mix with 2, 4-D @ 0.5kg a. i /ha at 32 days after gives significantly highest net returns Rs. 817.7 and Rs. 919.7 during 2011-12 and 2012-13, respectively. The higher net returns under isoproturon @ $1 \mathrm{~kg}$ a. i /ha tank mix with 2, 4-D @ 0.5kg a. i /ha at 32 days after sowing was due to lower cost of herbicides.
\end{abstract}

Key Words : Wheat, Herbicides, Integrated weed management, Yield

View Point Article : Shah, Rayees A. (2017). Evaluation of growth, yield attributing characters, yield and economics of wheat (Triticum aestivum L.) in integrated weed management practice under the temperate conditions of Kashmir. Internat. J. agric. Sci., 13 (2) : $378-384$, DOI:10.15740/HAS/IJAS/13.2/378-384.

Article History : Received : 09.03.2017; Revised : 05.05.2017; Accepted : 19.05.2017 